\title{
PEMURNIAN CRUDE GLYCERINE MELALUI PROSES BLEACHING DENGAN MENGGUNAKAN KARBON AKTIF
}

\author{
M. Afif Aufari, Sia Robianto, Renita Manurung \\ DepartemenTeknik Kimia, Fakultas Teknik, Universitas Sumatera Utara, \\ Jl.Almamater Kampus USU, Medan 20155, Indonesia. \\ E-mail : M.Afif Aufari@ Student.usu.ac.id.
}

\begin{abstract}
Abstrak
Crude glycerine merupakan cairan kental yang memiliki konsetrasi gliserin maximal $88 \%$. Crude glycerine memilki zat warna yang dihasilkan oleh karoten. Karoten atau biasa disebut dengan pigmen warna kuning kemerahan menyebabkan warna minyak sawit menjadi kuning kemerahan. Karoten larut dalam minyak dan lemak tetapi tidak larut dalam air. Warna yang demikian memiliki kualitas yang rendah dan kurang disukai konsumen sehingga harus dihilangkan. Senyawa ini dapat di hilangkan dengan proses absorbsi menggunakan karbon aktif. Pemanfaatan crude gliserin lebih lanjut akan menghasilkan produk industri obat - obatan maupun kosmetik. Penelitian dilakukan untuk mengetahui berapa daya serap karbon aktif terhadap kotoran crude glycerine yang menyebabkan warna kuning kemerahan. Penelitian dilakukan dengan menggunakan variasi mesh, berat dan waktu pengadukan yang berbeda
\end{abstract}

Kata Kunci : crude glycerine, karoten, karbon aktif

\begin{abstract}
Crude glycerine is a concentrated liquid that with the glycerin content less than $88 \%$. Crude glycerine has the dye produced by caroten. Caroten or usually called reddish yellow colour pigments cause the palm oil colour to be reddish yellow. Caroten is soluble in oil and fat but not in the water. Colours has a low quality and did not preferred by consumer and must be eliminated. This compound can be eliminated by a absorption process using activated carbon. The using of crude glycerine will further produce the product drugs and cosmetics industries. This research is conducted to study absorbtion of activated carbon to the crude glycerine impurities that causes the raddish yellow colour. This research do by using mesh, weight, and time of stirring with different variated.
\end{abstract}

Keyword : crude glycerine, caroten, activated carbon

\section{Pendahuluan}

PT. Flora Sawita Chemindo adalah salah satu diantara pabrik yang mengolah CPO (Crude Palm Oil) dan PKO (Palm Kernel Oil) dengan menghasilkan gliserin dari hasil samping proses produksi asam lemak. PT. Flora Sawita Chemindo yang terletak dikawasan Industri Medan ini memproduksi asam lemak dan gliserin dengan kapasitas 180 ton/hari. Adapun proses produksi yang dilakukan untuk menghasilkan gliserin dan asam lemak yaitu melalui proses sebagai berikut. CPO dan PKO terlebih dahulu dipompakan ke tangki Degumming untuk memisahkan minyak dari gum dan kotoran lainnya kemudian dipompakan ke Fat Splitting. Dalam reaktor ini terjadi hidrolisa antara minyak dan air hingga menghasilkan gliserin dan asam lemak. Gliserin yang terpisah dari ikatannya disebut gliserol. Gliserol ini biasanya mengandung gliserin kira-kira $15-18 \%$, maka untuk mendapatkan gliserin dengan konsentrasi yang lebih tinggi dilakukan evaporasi. Gliserin yang dihasilkan setelah evaporasi yaitu gliserin yang masih kotor atau disebut dengan Crude Glycerine dimana gliserin ini masih banyak mengandung kotoran diantaranya adalah minyak, posphoric acid, air sehingga mengakibatkan warna pada gliserin ini tidak bening melainkan berwarna kuning kemerahan. Selanjutnya gliserin ditambahkan $\mathrm{NaOH}$ untuk menaikkan $\mathrm{pH}$ menjadi 11,5 - 12,5 yang digunakan untuk menyabunkan agar mengurangi kadar minyak yang terdestilasi. [1] Kualitas gliserin hasil dari destilasi ini masih belum memenuhi standar nilai jual di pasar oleh sebab itu peneliti ingin melakukan penelitian mengenai pemurnian gliserin melalui proses bleaching dengan menggunakan karbon aktif.

Pada saat proses bleaching, peneliti menggunakan karbon aktif untuk memurnikan gliserin dari kandungan kotoran. Pada penelitian sebelumnya telah dimanfaatkan karbon aktif sebagai adsorben untuk memurnikan minyak jelantah menjadi biodiesel. Maka dalam hal ini peneliti menggunakan karbon aktif untuk memurnikan gliserin karena karbon aktif adalah adsorben alternatif untuk menyerap zat organik yang menyebab warna kuning kemerahan pada crude glycerine yaitu minyak, posphoric acid, air. [2] 
Dari latarbelakang tersebut maka dapat disusun suatu rumusan masalah yaitu apakah karbon aktif dapat digunakan untuk memurnikan zat kotoran pada crude glycerine yang menyebabkan warna crude glycerine menjadi kuning kemerahan. Tujuan dari penelitian ini adalah untuk mengetahui berapa daya serap karbon aktif terhadap kotoran dalam crude glycerine yang menyebabkan warna kuning kemerahan.

\section{Teori}

CPO, PKO, dan RBDPS adalah merupakan salah satu bahan baku olahan yang dipakai suatu pabrik oleokimia, yang mana menghasilkan fatty acid dan hasil gliserin sampingnya. Salah satu pabrik oleokimia yang mengolah CPO, PKO, dan RBDPS yaitu PT. Flora Sawita Chemindo.

\section{Gliserin}

Gliserin pertama kali ditemukan oleh Scheele pada tahun 1779 pada produk safonifikasi dari minyak zaitun dan kemudian diperkenalkan sebagai kandungan umum lain dari minyak dan lemak. Chevreul memberikan nama gliserin dan menjelaskan bentuk alamiahnya dari kombinasi dengan lemak dan minyak. Gliserin atau gliserol merupakan trihidric alkohol mengandung radikal trivalen gliserin $\left(\mathrm{C}_{3} \mathrm{H}_{5}\right)$.

Gliserin merupakan cairan kental yang tak berwarna dengan berat molekul 92, berat jenis 1,25 $\mathrm{gr} / \mathrm{cm}^{3}$ dan mempunyai titik didih yang tinggi serta terurai pada suhu $290^{\circ} \mathrm{C}$.

Gliserin merupakan senyawa yang mempunyai gugus hidroksil lebih dari dua atau merupakan tiga senyawa alkohol yang saling berkaitan dengan nama 1, 2,3-propanatriol yang bentuk molekul sebagai berikut :

$$
\begin{aligned}
& \mathrm{CH}_{2}-\mathrm{OH} \\
& \stackrel{\mathrm{CH}}{\mathrm{I}}-\mathrm{OH} \\
& \mathrm{CH}_{2}-\mathrm{OH}
\end{aligned}
$$

\section{Keberadaan Gliserin}

Gliserin juga terjadi secara alami seperti trigliserida pada seluruh sel hewan dan tumbuhan dalam bentuk lipida seperti lisitin dan sepalin.

Istilah gliserol hanya digunakan untuk senyawa murni 1, 2, 3, - propanatriol, $\left(\mathrm{CH}_{2} \mathrm{OH}-\mathrm{CHOH}-\right.$ $\mathrm{CH}_{2} \mathrm{OH}$ ). Istilah gliserin digunakan untuk produk komersil yang dimurnikan. Biasanya mengandung $95 \%$ atau lebih. Berbagai tingkatan gliserin tersedia secara komersial. Hal tersebut agak membedakan kandungan gliserin dalam berbagai karateristik seperti warna, bau, dan logam pengotor. Akhiran - ol pada gliserol mengandung arti keberadaan gugus hidroksil. Pengucapan gliserin adalah jarang karena akhiran ini secara kimia menandakan basa dan tidak dipakai pada gliserin. Kedua istilah ini digunakan tanpa perbedaan dalam penggunaan secara komersil.

Suatu metode untuk penamaan ester dari gliserol dengan asam organik yang mempunyai nama sederhana adalah mengubah "ic acid" dengan "in", contohnya 1-monophormin (gliserol 1-monophormate), tributirin (gliserol tributirate). Tingkat esterifikasi ditandai oleh awalan mono, di, dan tri.

Pemucatan (Bleaching) adalah usaha untuk menghilangkan zat warna alami dan zat warna lain yang merupakan degradasi zat alamiah, pengaruh logam dan warna akibat oksidasi. Pemucatan dilakukan dengan mencampur minyak dengan sejumlah besar adsorben, seperti tanah serap (fuller earth), lempung dan arang aktif atau dapat juga bahan kimia. Adsorben yang digunakan untuk memucatkan minyak terdiri dari tanah pemucat (bleaching earth) dan arang (carbon earth). Zat warna dalam minyak akan diserap oleh permukaan adsorben dan juga menyerap suspensi koloid (gum dan resin) serta hasil degradasi minyak, misalnya peroksida. [3]

Karbon aktif merupakan senyawa karbon amorph, yang dapat dihasilkan dari bahan - bahan yang mengandung karbon atau dari arang yang diperlukan dengan cara khusus untuk mendapatkan permukaan yang lebih luas. Karbon aktif dapat mengadsorpsi gas dan senyawa - senyawa kimia tertentu atau sifat adsorpsinya selektif, tergantung pada besar atau volume pori - pori dan luas permukaan. Daya serap sangat besar, yaitu $25-1000 \%$ terhadap berat arang aktif. Karena hal tersebut maka karbon aktif banyak digunakan oleh kalangan industri. Karbon aktif adalah material yang berbentuk butiran atau bubuk yang berasal dari material yang mengandung karbon misalnya batubara, kulit kelapa, ampas tebu dan lain sebagainya. [5]

Karbon aktif dipakai dalam proses pemurnian udara, gas, dan larutan atau cairan, dalam proses pemurnian suatu logam dari biji logamnya, dan juga dipakai sebagai katalis pendukung. Dipakai juga dalam pemurnian gas dan udara, masker dan respirator, seragam militer, industri nuklir, deklorinasi, penyerapan rasa dan bau dari air, aquarium, filter pada rokok dan juga penghilang senyawa - senyawa organik dalam air. Dengan gaya Van der Walls yang dimilikinya, pori - pori yang sangat luas ini mampu menangkap berbagai macam bahan. Oleh karena itu arang aktif dapat digunakan pada kasus overdosis obat, keracunan makanan, atau tertelan bahan beracun.

Saat ini karbon aktif telah digunakan secara luas dalam industri kimia, makanan/minuman dan farmasi. Pada umumnya karbon aktif digunakan sebagai bahan penyerap, dan penjernih. Menurut Standard Industri Indonesia (SII No. 0258-79) persyaratan karbon aktif dapat dilihat pada tabel 1. [3] 
Tabel 1. Standar Mutu Karbon Aktif.

\begin{tabular}{|l|c|l|}
\hline \multicolumn{1}{|c|}{ Jenis Uji } & Satuan & Persyaratan \\
\hline $\begin{array}{l}\text { 1. Bagian yang hilang pada } \\
\text { pemanasan } 950^{\circ} \mathrm{C}\end{array}$ & $\%$ & Maksimum 15 \\
\hline 2. Air & $\%$ & $\begin{array}{l}\text { Maksimum 10 } \\
2,5\end{array}$ \\
\hline 3. Abu & $\%$ & Tidak ternyata \\
\hline $\begin{array}{l}\text { 4. Bagian yang tidak } \\
\text { mengarang }\end{array}$ & $\%$ & Maksimum 20 \\
\hline $\begin{array}{l}\text { 5. Daya serap terhadap } \\
\text { larutan I2 }\end{array}$ & \\
\hline
\end{tabular}

Pembentukan Karbon Aktif

Pembuatan karbon aktif dapat dibuat dari berbagai bahan arang seperti kayu, arang dan kulit kacang, dapat melalui dua proses yaitu :

a. Reaktivasi Fisik : prekursor ditambahkan ke arang aktif dengan gas menggunakan salah satu cara atau gabungan dari ;

- Arangisasi : bahan arang dipirolisi pada suhu $600-900^{\circ} \mathrm{C}$ tanpa udara (biasanya dengan gas inert seperti argon )

- Aktivasi / Oksidasi : bahan arang dimasukkan dalam atmosfer pengoksidasi (arang dioksida, oksigen atau uap air ) pada suhu diantara $600-1200^{\circ} \mathrm{C}$.

b. Aktivasi kimia : perendaman dengan bahan asam seperti asam fosfat atau basa seperti kalium hiddroksida, natrium hidroksida atau garam seperti seng klorida, diikuti dengan arangisasi pada temperatur $450-900^{\circ} \mathrm{C}$. Tahap aktivasi / arangisasi berjalan bersamaan dengan aktivasi kimia. Cara ini dapat menjadi masalah dalam beberapa kasus, contonya, masing adanya sisa seng pada hasil akhir.

Aktivasi kimia lebih disukai dari pada aktivasi fisik karena memiliki suhu yang lebih rendah dan waktu yang lebih cepat untuk mengaktifkan bahan. [5]

Istilah gliserin digunakan untuk produk komersil yang di murnikan biasanya mengandung $95 \%$ atau lebih gliserol dalam berbagai karakteristik seperti warna bau dan logam pengotor. [4]

\section{Metodologi Penelitian}

Penelitian ini dilakukan di Laboratorium Penelitian, Departemen Teknik Kimia, Fakultas Teknik, Universitas Sumatera Utara.

Tabel 2. Rancangan Percobaan

\begin{tabular}{|c|c|c|c|}
\hline Run & $\begin{array}{c}\text { Ukuran } \\
\text { (mesh) }\end{array}$ & $\begin{array}{c}\text { Berat } \\
\text { (gram) }\end{array}$ & $\begin{array}{c}\text { Waktu } \\
\text { (menit) }\end{array}$ \\
\hline 1 & 100 & 0,5 & 15 \\
\hline 2 & 100 & 0,5 & 30 \\
\hline 3 & 100 & 0,5 & 45 \\
\hline 4 & 100 & 1 & 15 \\
\hline 5 & 100 & 1 & 30 \\
\hline 6 & 100 & 1 & 45 \\
\hline 7 & 100 & 1,5 & 15 \\
\hline 8 & 100 & 1,5 & 30 \\
\hline 9 & 100 & 1,5 & 45 \\
\hline 10 & 150 & 0,5 & 15 \\
\hline 11 & 150 & 0,5 & 30 \\
\hline 12 & 150 & 0,5 & 45 \\
\hline 13 & 150 & 1 & 15 \\
\hline 14 & 150 & 1 & 30 \\
\hline 15 & 150 & 1 & 45 \\
\hline 16 & 150 & 1,5 & 15 \\
\hline 17 & 150 & 1,5 & 30 \\
\hline 18 & 150 & 1,5 & 45 \\
\hline
\end{tabular}

Pada tabel 2 bisa kita lihat ukuran mesh yang digunakan adalah 100 mesh dan 150 mesh, dengan berat $0,5 \mathrm{gr}, 1 \mathrm{gr}$ dan 1,5 gr, Waktu pengadukan adalah 15 menit, 30 menit, dan 45 menit. Dari rancangan percobaan tersebut maka kita dapat melakukan penelitian sesuai dengan rancangan percobaan.

Prosedur

Bahan yang digunakan dalam percobaan ini adalah bahan hasil produk evaporasi yang masih berupa crude glycerine dari pabrik PT. Flora sawita Chemindo.

Prosedur Pemurnian Crude Glycerine dengan Menggunakan Karbon Aktif.

a. Ditimbang karbon aktif dengan variasi berat tertentu.

b. Ditambahkan $100 \mathrm{ml}$ crude gliserin untuk proses penyerapan.

c. Diaduk hingga homogen.

d. Didiamkan beberapa menit dengan variasi waktu tertentu yang sesuai pada rancangan percobaan.

e. Kemudian disaring dengan menggunakan kertas saring pada keadaan vakum.

f. Lalu diukur adsorbansi dengan menggunakan spektrofotometer visibel. 


\section{Hasil dan Pembahasan}

Hasil dari pemurnian Crude Glycerine melalui proses bleaching dengan menggunakan karbon aktif ini dapat dilihat dari nilai absorbansi zat warna pada Crude Glycerine. Setelah dilakukan penelitian, maka diperoleh hasil sebagai berikut :

Absorbansi Crude Glycerine sebelum di bleaching 4,310 A.

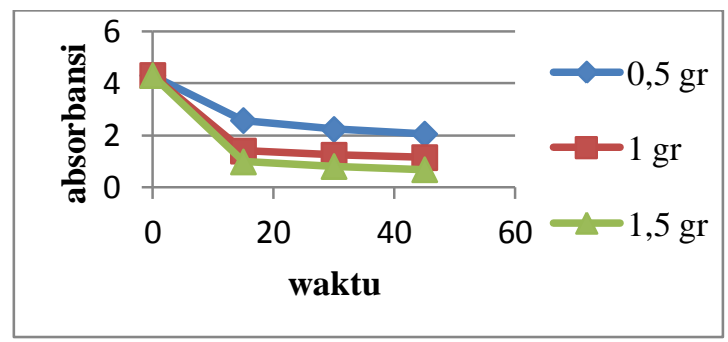

Gambar 1. Hubungan absorbansi terhadap waktu dengan ukuran karbon aktif 150mesh

Dari gambar 1 dapat dilihat bahwa hubungan antara absorbansi dengan waktu dimana semakin lama waktu pengadukan maka nilai absorbansi yang didapat semakin kecil, begitu juga dengan berat, semakin berat arang aktif yang digunakan maka nilai absorbansi juga semakin kecil.. Hal ini sesuai dengan teori dimana jumlah arang aktif yang digunakan untuk menyerap warna berpengaruh terhadap jumlah warna yang diserap. semakin banyak arang aktif yang di gunakan maka nilai absorbansi yang didapat semakin kecil [4]. Namun jika dilihat dari gambar 1 tersebut maka pada berat 0,5 gr terjadi sedikit penurunan yang berbeda pada berat yang lainnya, hal ini terjadi karena adanya penyimpangan - penyimpangan pada saat penelitian, misalnya pada saat pengadukan.

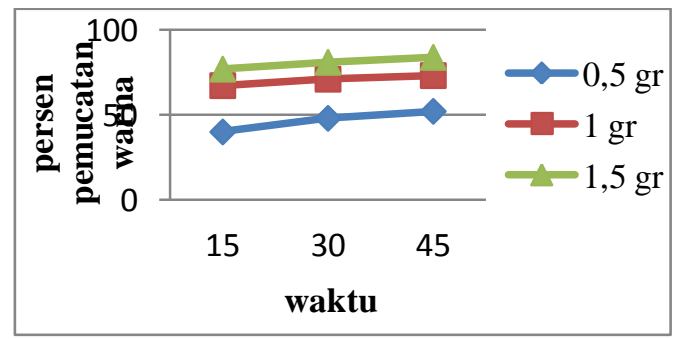

Gambar 2. Persen pemucatan warna terhadap waktu dengan variasi berat pada ukuran 150 mesh

Jika dilihat dari gambar 2 dapat kita ambil kesimpulan bahwa waktu tidak terlalu berpengaruh pada proses pemucatan ,namun jika di hubungkan kembali dengan gambar 1 yaitu hubungan absorbansi terhadap waktu maka dapat dilihat proses pemucatan warna terjadi pada mula - mula yaitu pada menit ke 15 setelah itu pada menit ke 30 dan 45, proses pemucatan warna terjadi semakin kecil. Disini persen pemucatan warna sangat terlihat jelas yaitu pada berat 0,5 gr persen pemucatan warna mencapai $40,1 \%$, untuk berat $1 \mathrm{gr}$ persen pemucatan warna mencapai $67,3 \%$ dan untuk berat 1,5 gr persen pemucatan warna mencapai $77,0 \%$, sedangkan pada waktu 30 menit dan 45 menit kita dapat lihat persen pemucatan warna hanya mengalami sedikit kenaikan saja yaitu sekitar $2 \%-4 \%$ saja. Dalam hal ini dapat kita simpulkan bahwa waktu tidak berpengaruh pada pemucatan warna tetapi berat karbon aktif sangat berpengaruh pada persen pemucatan warna.

Dari gambar 3 maka dapat kita lihat bahwa hubungan absorbansi terhadap waktu sama halnya dengan gambar 1 , pada ukuran 100 mesh ini juga terlihat pada berat 0,5 gr terjadi sedikit penurunan yang berbeda pada berat yang lainnya, hal ini terjadi karena adanya penyimpangan - penyimpangan pada saat penelitian, misalnya pada saat pengadukan.

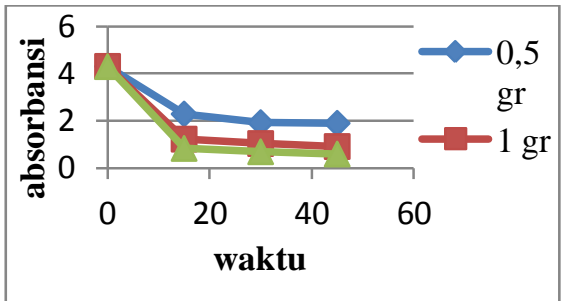

Gambar 3. Hubungan absorbansi terhadap waktu dengan ukuran karbon aktif 100 mesh

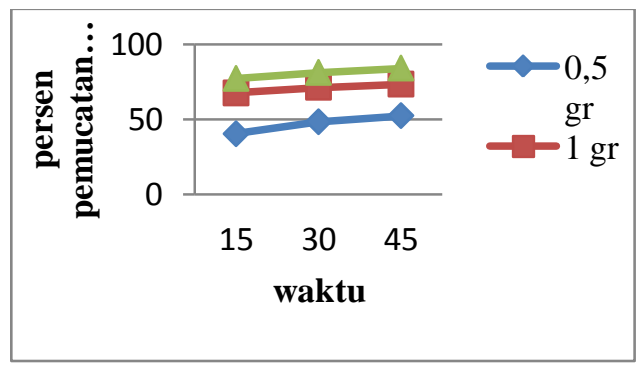

Gambar 4. Persen pemucatan warna terhadap waktu dengan variasi berat pada ukuran 100 mesh

Pada gambar 4 sama halnya dengan gambar 2, $\mathrm{m}$ dapat kita ambil kesimpulan bahwa waktu tidak terlalu berpengaruh pada proses pemucatan ,namun jika di hubungkan kembali dengan gambar 3 maka dapat dilihat proses pemucatan warna terjadi pada mula - mula yaitu pada menit ke 15 setelah itu pada menit ke 30 dan 45 proses pemucatan warna terjadi semakin kecil. Disini persen pemucatan warna sangat terlihat jelas yaitu pada berat 0,5 gr persen pemucatan 
warna mencapai $46,9 \%$. Untuk berat 1 gr persen pemucatan warna mencapai $71,7 \%$ dan untuk berat 1,5 gr, persen pemucatan warna mencapai $76,8 \%$, sedangkan pada waktu 30 menit dan 45 menit kita dapat lihat persen pemucatan warna hanya mengalami sedikit kenaikan saja yaitu sekitar 2\%$4 \%$ saja. Dalam hal ini dapat kita simpulkan bahwa waktu tidak berpengaruh pada pemucatan warna tetapi berat karbon aktif sangat berpengaruh pada persen pemucatan warna, ini sama halnya dengan gambar 2.

\section{Konsentrasi Crude Glycerine Terhadap Jumlah Karbon aktif}

Konsentrasi awal Crude Glycerine $=88 \%$

Pada tabel 3 dapat dilihat hubungan konsentrasi Crude Glycerine sama besar terhadap waktu pengadukan begitu juga dengan ukuran mesh yang digunakan, namun terhadap berat karbon aktif konsentrasi Crude Glycerine mengalami sedikit penurunan. Maka dapat disimpulkan bahwa karbon aktif yang digunakan merupakan absorben yang baik digunakan untuk menyerap zat warna pada Crude Glycerine, namun dalam hal ini Crude Glycerine mengalami penyimpangan yaitu terjadinya penurunan konsentrasi yaitu $<88 \%$, kesimpulannya dalam hal ini adalah untuk menyerap zat warna karbon aktif memang adsorben yang sangat baik.

Tabel 3. Hubungan konsentrasi Crude Glycerine terhadap waktu dengan ukuran 100 mesh

\begin{tabular}{|c|c|c|c|}
\hline \multirow{2}{*}{ Berat } & \multicolumn{3}{|c|}{ konsentrasi Crude Glycerine pada } \\
& 15 menit & 30 menit & 45 menit \\
\cline { 2 - 4 } & 15 gerbai Waktu \\
\hline 0,5 gr & 87,53 & 87,53 & 87,53 \\
\hline 1 gr & 86,85 & 86,85 & 86,85 \\
\hline 1,5 gr & 86,17 & 86,17 & 86,17 \\
\hline
\end{tabular}

\section{Kesimpulan}

Dari penelitian dapat di ambil kesimpulan bahwa karbon aktif dapat menyerap zat warna pada Crude Glycerine yang paling baik adalah ukuran 150 mesh dengan berat 1,5 gr dan pada waktu 45 menit.

\section{Ucapan terima Kasih}

Pelaksanaan penelitian ini tidak terlepas dari bantuan berbagai pihak, peneliti menyampaikan penghargaan dan rasa cinta kasih yang sedalam dalamnya kepada seluruh orang yang senantiasa memberikan dukungan / dorongan moril ataupun materil hingga pada kesempatan ini. Peneliti juga mengucapkan terima kasih kepada PT. Flora Sawita chemindo yang telah membantu saya dengan memberi fasilitas yang saya perlukaan untuk pelaksanaan penelitian ini.

\section{Daftar Pustaka}

[1] Anonim, 2009, Work Instruction, PT. Flora Sawita Chemindo, QA Departemen, Tanjung Morawa, 2009

[2] Carl, S. Miner and N. N. Dalton, Glycerine, Ranhold Published Corporation Newyork, 1953.

[3] Ketaren., Minyak dan Lemak Pangan, Balai Pustaka, Jakarta, 1986.

[4] Kirk, R. E. Othmer, D. F., Encyclopedia of Chemical Engineering Technology, Jhon Wiley and Sons Inc, New York, 1971.

[5] Leonard, S.R., Skripsi Penentuan Kapasitas Penyerapan Zat Warna Oleh Arang Sekam Padi, Journal Analyitical Chemistry, FMIPA ITB, Bandung, 2009. 